\title{
Correlation and Path Analysis in
} Annual Chrysanthemum [Chrysanthemum coronarium L.]

\author{
M.P. Bindhushree*, B.C. Patil, Mukund Shiragur, Sateesh R. Patil, \\ Amruta S. Bhat and Dileep Kumar A. Masuthi
}

Department of Floriculture and Landscape Architecture, Kittur Rani Channamma College of Horticulture, Arabhavi - 591 218, Karnataka, India

*Corresponding author

\section{A B S T R A C T}

The study was conducted during the year 2018-2019 at Department of Floriculture and Landscape Architecture, Kittur Rani Channamma Collage of Horticulture, Arabhavi.

\section{Keywords}

Correlation and path analysis,

Chrysanthemum

Article Info

Accepted:

15 August 2019

Available Online:

10 September 2019 to study the correlation and path analysis in twenty different annul chrysanthemum genotypes. The Correlation studies revealed highly significant and positive association of flower yield per plant with individual flower weight (0.922), days to harvest (0.773), number of flowers per plant (0.709), plant height (0.614), number of secondary branches $(0.571)$, duration of flowering (0.433) and number of leaves (0.407) suggesting the possibility of simultaneous selection for these traits for improving yield. Path analysis showed that flower yield per plant was significantly and directly influenced by individual flower weight (1.165), number of flowers per plant (0.551), days for 50\% flowering (0.318), number of leaves (0.342), plant spread in East-West (0.098), North-South direction (0.006), and number of primary branches (0.026) which indicated the possibility of increasing flower yield by selecting these characters directly.

\section{Introduction}

Glebionis coronaria, formerly called Chrysanthemum coronarium L. is an important member of daisy family or Asteraceae. It is a branching annual with finely cut foliage reaching height up to a meter, size of the flower varies from $2.5-4 \mathrm{~cm}$ in diameter and color is usually in shades of yellow and white having single or double forms (Desai, 1962) with cream zones at the centre (Vishnuswarup, 1967). It is supplementing the production of Florist chrysanthemum in many areas of our country and is occupying an area of about 5 per cent of total area under chrysanthemum, Annual chrysanthemum differs from the Florist's chrysanthemum in many aspects such as, relatively short duration, less photosensitive, grows taller, more vigorous and hardy. It is used as a leafy vegetable, flowers are edible and petals are used fresh or dried as a garnish or to brew a tea. It produces large sized attractive blooms for making garlands and for 
decorations during the religious rituals. As a cut flower it makes bold arrangement due to the availability of a long stems (Desai, 1962).

Yield is a complex character resulting from multiplicative interactions of various components. Therefore, correlation studies between yield and other traits will be of interest to breeders in planning the hybridization programme and evaluating the individual plants in segregating populations.

The correlation between various components and yield can present a confusing picture, for this reason path coefficient affords a much more realistic interpretation of the factor involved. Therefore, it is imperative to use the technique of path analysis by which analysis of correlation as a system of related variable is possible.

The presence and magnitude of genetic variability in a gene pool is the pre-requisite of a breeding programme (Bhujpal et al., 2013). Apart from this correlations as well as path coefficient are important tools for the selection of desirable traits and to enhance the productivity of the annual chrysanthemum. The main objective for a plant breeder is to evolve high yielding varieties. It is therefore, desirable for plant breeder to know the extent of relationship between yield and its various components, which will facilitate selection based on component traits (Prasad et al., 2011). Keeping in view the above facts present investigation was undertaken with an objective to analyze and determine the traits having greater interrelationship with flower yield utilizing the correlation and path analysis and to help breeders in improvement of annual chrysanthemum.

\section{Materials and Methods}

The study was conducted during the year 2018-2019 at Department of Floriculture and
Landscape Architecture, Kittur Rani Channamma Collage of Horticulture, Arabhavi. Investigation was carried out in randomized complete block design, with two replications and twenty different annual chrysanthemum genotypes, which represent diverse characters. One month old seedling were transplanted into the main field with spacing of $30 \times 30 \mathrm{~cm}$. Observations were recorded for best 5 plants in each genotype for plantheight $(\mathrm{cm})$, number of primary and secondary branches per plant, plant spread in East-West and North-South direction $(\mathrm{cm})$, number of leaves, leaf area, days taken for flower bud initiation, days to 50 percent flowering, days taken for complete flowering, days to harvest, duration of flowering (days), number of flowers per plant, individual flower weight (g), flower yield (g/plant), flower yield per plot, flower yield per hectare, test weight and seed yield (g/plant). The observations were recorded at an interval of 30 days from transplanting till completion of harvest.

The estimates of correlation coefficient were done by the method suggested by Hayes et al., (1955) and Al-jibouri et al., (1958). The path coefficient analysis was carried out by using the technique outlined by Dewey and Lu (1959) for flower yield and its components keeping flower yield as resultant variable and its component as causal variables.

\section{Results and Discussion}

\section{Association analysis}

The simple correlation coefficients between yield and various yield components and interrelationship among the traits were computed and they are presented in Table 1. The results obtained through the correlation coefficients indicate a strong association between plant morphological characters with yield. A positive correlation between desirable characters is favorable to the plant breeder 
which helps in simultaneous improvement. In general, genotypic correlation was higher than phenotypic correlations for most of the characters studied. Genotypic correlation also provide an estimate of inherent association between genes controlling any two characters thus formulating an effective selection scheme. Further the phenotypic expression of correlation is reduced due to the influence of environment.

Correlation studies revealed highly significant and positive association of flower yield per plant with individual flower weight (0.922), days to harvest (0.773), number of flowers per plant (0.709), plant height (0.614), number of secondary branches (0.571), duration of flowering (0.433) and number of leaves(0.407), suggesting the possibility of simultaneous selection for these traits for improving yield.

Similar trend was observed for correlation of plant height with flower yield per plant by Basavaraju (2006) in dahlia, Suvija et al., (2016), Atul et al., (2018) in chrysanthemum. Singh and Singh (2005) in marigold also reported the same result for correlation with number of flowers per plant with individual flower weight, Number of flowers per plant showed significant and positive correlation with flower yield per plant. Similar results were shown by Ravikumar and Patil (2003) and Naik et al., (2004) in China aster, Suvija et al., (2016) in chrysanthemum,

Plant height exhibited significant and positive correlation with number of primary branches (0.323), number of secondary branches (0.890), number of leaves (0.883), individual flower weight (0.487), days to harvest (0.528), number of flowers per plant (0.882) and flower yield per plant (0.614). Correlation of plant height with number of leaves is in accordance with Ranchana et al., (2013) in tuberose.
Thus selection of taller plants result in wider canopy, higher yield owing to increase in photosynthetic area. Similar trend was observed for correlation of plant height with flower yield per plant by Basavaraju (2006) in dahlia.

\section{Path analysis}

Yield is a complex character and is composed of component characters which contribute directly as well as indirectly through each other. The study of correlation alone when considered on the criteria for selection for high yield would be misleading. Since a character may not be directly correlated with yield but may be depend on other characters, by path analysis it is possible to find out the direct and indirect influence of component characters on the yield. The technique of path analysis developed by Wright (1921) and demonstrated by Dewey and Lu (1959) facilitates in partitioning the correlation coefficients into direct and indirect contribution of various characters to the yield. The simple correlation coefficient of annual chrysanthemum was apportioned into direct effects and indirect effects by path analysis and the results are presented in Table 2.

The residual effect (0.0237) of the path analysis was low, indicating that the character considered for path analysis was appropriate.

Path analysis showed that flower yield per plant was significantly and directly influenced by individual flower weight (1.165), which is in accordance with the results of Kameshwari et al., (2015), Suvija et al., (2016) and Hebbal et al., (2018) in chrysanthemum, number of flowers per plant (0.551), Deka and Paswan (2002) in chrysanthemum reported similar association with number of flowers per plant, days for $50 \%$ flowering (0.318), number of leaves (0.342). 
Table.1 Estimates of genotypic correlation coefficients in annual chrysanthemum genotypes

\begin{tabular}{|c|c|c|c|c|c|c|c|c|c|c|c|c|c|c|c|}
\hline $\begin{array}{c}\text { Trait } \\
\text { no }\end{array}$ & 1. & 2. & 3. & 4. & 5. & 6. & 7. & 8. & 9. & 10. & 11. & 12. & 13. & 14 & 15 \\
\hline 1 & 1.000 & -0.200 & -0.172 & $0.323 *$ & $\begin{array}{c}0.890 * \\
*\end{array}$ & $-0.375^{*}$ & $0.883 * *$ & $0.487 * *$ & $0.528 * *$ & $0.882 * *$ & -0.274 & 0.051 & $-0.064 * *$ & -0.003 & $0.614 * *$ \\
\hline 2 & & 1.000 & $0.323^{*}$ & $-0.498 * *$ & -0.168 & $0.573 * *$ & $-0.316^{*}$ & 0.148 & -0.185 & -0.074 & -0.164 & $0.322 *$ & 0.164 & -0.294 & 0.192 \\
\hline 3 & & & 1.000 & -0.306 & -0.171 & $0.586 * *$ & -0.044 & -0.077 & -0.251 & $-0.407 * *$ & -0.106 & $0.403 * *$ & 0.181 & -0.257 & -0.207 \\
\hline 4 & & & & 1.000 & 0.125 & -0.263 & 0.309 & -0.032 & 0.176 & $0.392 *$ & -0.139 & $-0.366^{*}$ & $-0.363^{*}$ & 0.104 & 0.057 \\
\hline 5 & & & & & 1.000 & $-0.357 *$ & $0.838 * *$ & $0.492 * *$ & $0.554 * *$ & $0.748 * *$ & -0.192 & 0.119 & $-0.581 * *$ & 0.053 & $0.571 * *$ \\
\hline 6 & & & & & & 1.000 & $-0.373 *$ & $-0.318 *$ & $-0.671 * *$ & $-0.485^{* * *}$ & -0.265 & -0.125 & 0.223 & $-0.430 * *$ & $-0.388 *$ \\
\hline 7 & & & & & & & 1.000 & 0.262 & $0.405 * *$ & $0.751 * *$ & -0.140 & 0.065 & $-0.502 * *$ & 0.130 & $0.407 * *$ \\
\hline 8 & & & & & & & & 1.000 & $0.849 * *$ & $0.481 * *$ & 0.004 & $0.577 * *$ & -0.159 & 0.150 & $0.922 * *$ \\
\hline 9 & & & & & & & & & 1.000 & $0.561 * *$ & 0.234 & $0.562 * *$ & -0.067 & $0.416 * *$ & $0.773 * *$ \\
\hline 10 & & & & & & & & & & 1.000 & -0.212 & 0.042 & $-0.567 * *$ & 0.056 & $0.709 * *$ \\
\hline 11 & & & & & & & & & & & 1.000 & $0.370^{*}$ & $0.793 * *$ & $0.898 * *$ & $-\mathbf{0 . 1 2 7}$ \\
\hline 12 & & & & & & & & & & & & 1.000 & $0.430 * *$ & 0.286 & $0.433 * *$ \\
\hline 13 & & & & & & & & & & & & & 1.000 & $0.569 * *$ & $-0.363^{*}$ \\
\hline 14 & & & & & & & & & & & & & & 1.000 & 0.053 \\
\hline 15 & & & & & & & & & & & & & & & 1.000 \\
\hline
\end{tabular}

*Significant at $\mathrm{P}=0.05 * *$ Significant at $\mathrm{P}=0.01$

r value at $5 \%=0.311$ and $1 \%=0.402$

1. Plant height $(\mathrm{cm})$

2. Plant spread $(\mathrm{cm})$ in $[\mathrm{E}-\mathrm{W}]$

3. Plant $\operatorname{spread}(\mathrm{cm})$ in $[\mathrm{N}-\mathrm{S}]$

4. Number of primary branches
5. Number of secondary branches 9. Days to harvest

6. Leaf area $\left(\mathrm{cm}^{2}\right)$

7. Number of leaves

8.Individual flower weight
10. Number of flowers per plant

11. Days for $50 \%$ flowering

12. Duration of flowering (days)
13. Days to flower bud initiation 14. Days for complete flowering 15. Flower yield per plant (g) 
Table.2 Estimates of genotypic path coefficient analysis in annual chrysanthemum genotypes.

\begin{tabular}{|c|c|c|c|c|c|c|c|c|c|c|c|c|c|c|c|}
\hline $\begin{array}{l}\text { Trait } \\
\text { No. }\end{array}$ & 1 & 2 & 3 & 4 & 5 & 6 & 7 & 8 & 9 & 10 & 11 & 12 & 13 & 14 & rG \\
\hline 1 & -0.570 & 0.113 & 0.098 & -0.183 & -0.507 & 0.214 & -0.503 & -0.277 & -0.300 & -0.502 & 0.156 & -0.029 & 0.366 & 0.001 & $0.614 * *$ \\
\hline 2 & -0.019 & 0.098 & 0.031 & -0.048 & -0.016 & 0.056 & -0.031 & 0.014 & -0.018 & -0.007 & -0.016 & 0.031 & 0.016 & -0.028 & 0.192 \\
\hline 3 & -0.001 & 0.001 & 0.006 & -0.001 & -0.001 & 0.003 & -0.002 & -0.004 & -0.001 & -0.002 & -0.006 & 0.002 & 0.001 & -0.001 & -0.207 \\
\hline 4 & 0.008 & -0.013 & -0.008 & 0.026 & 0.003 & -0.006 & 0.008 & -0.008 & 0.004 & 0.010 & -0.003 & -0.009 & -0.009 & 0.002 & 0.057 \\
\hline 5 & -0.044 & 0.008 & 0.008 & -0.006 & -0.049 & 0.017 & -0.041 & -0.024 & -0.027 & -0.037 & 0.009 & -0.005 & 0.028 & -0.002 & $0.571 * *$ \\
\hline 6 & 0.053 & -0.081 & -0.083 & 0.037 & 0.050 & -0.142 & 0.053 & 0.045 & 0.095 & 0.069 & 0.037 & 0.017 & -0.031 & 0.061 & $-0.388 *$ \\
\hline 7 & 0.302 & -0.108 & -0.014 & 0.105 & 0.286 & -0.127 & 0.342 & 0.089 & 0.138 & 0.257 & -0.048 & 0.022 & -0.171 & 0.044 & $0.407 * *$ \\
\hline 8 & 0.567 & 0.172 & -0.089 & -0.037 & 0.573 & -0.371 & 0.305 & 1.165 & 0.989 & 0.560 & 0.004 & 0.672 & -0.185 & 0.174 & $0.922 * *$ \\
\hline 9 & -0.197 & 0.069 & 0.094 & -0.066 & -0.207 & 0.251 & -0.152 & -0.318 & -0.375 & -0.210 & -0.087 & -0.210 & 0.025 & -0.155 & $0.773 * *$ \\
\hline 10 & 0.486 & -0.041 & -0.224 & 0.215 & 0.412 & -0.267 & 0.414 & 0.265 & 0.309 & 0.551 & -0.116 & 0.022 & -0.312 & 0.030 & $0.709 * *$ \\
\hline 11 & -0.087 & -0.052 & -0.033 & -0.044 & -0.061 & -0.084 & -0.044 & 0.001 & 0.074 & -0.067 & 0.318 & 0.117 & 0.252 & 0.285 & -0.127 \\
\hline 12 & -0.002 & -0.016 & -0.020 & 0.018 & -0.006 & 0.006 & -0.003 & -0.029 & -0.028 & -0.002 & -0.019 & -0.051 & -0.022 & -0.014 & $0.433 * *$ \\
\hline 13 & 0.117 & -0.030 & -0.033 & 0.066 & 0.106 & -0.040 & 0.092 & 0.029 & 0.012 & 0.103 & -0.145 & -0.078 & -0.183 & -0.104 & $-0.363^{*}$ \\
\hline 14 & 0.006 & 0.070 & 0.061 & -0.025 & -0.012 & 0.103 & -0.031 & -0.036 & -0.099 & -0.013 & -0.215 & -0.068 & -0.136 & -0.240 & 0.053 \\
\hline
\end{tabular}

Residual effect $=0.00237$ Bold diagonal figures indicate direct effect

1. Plant height $(\mathrm{cm})$

2. Plant spread $(\mathrm{cm})$ in $[\mathrm{E}-\mathrm{W}]$

3. Plant spread $(\mathrm{cm})$ in $[\mathrm{N}-\mathrm{S}]$

4. Number of primary branches
*Significant at $\mathrm{P}=0.005$

5. Number of secondary branches

6. Leaf area $\left(\mathrm{cm}^{2}\right)$

7. Number of leaves

8. Individual flower weight
rG = Genotypic correlation coefficient of flower yield per plant $* *$ Significant at $\mathrm{P}=0.01$

9. Days to harvest

10. Number of flowers per plant

11. Days for $50 \%$ flowering

12.Duration of flowering (days)
13. Days to flower bud initiation

14. Days for complete flowering

15. Flower yield per plant (g) 
Basavaraju (2006) in dahlia reported similar association with number of leaves and days for $50 \%$ flowering. plant spread in EastWest (0.098), North-South direction (0.006), and number of primary branches (0.026) which indicated the possibility of increasing flower yield by selecting these characters directly.

Negative direct effect was observed through plant height $(-0.570)$, leaf area (-0.142), days to harvest $(-0.375)$, duration of flowering ($0.051)$, days to flower bud initiation ($0.183)$, days for complete flowering $(-0.240)$ and number of secondary branches (-0.049).

\section{References}

Desai, B. L., 1962, Chrysanthemum. In: Seasonal flowers, Eds. Desai, B. L., Indian Council of Agricultural Research, New Delhi, 64-65.

Bhujbal, G. B., Chavan, N. G. and Mehetre, S. S. 2013. Evaluation of genetic variability heritability and Genetic advances in gladiolus (Gladiolus grandiflorus L.) genotypes. The Bioscan. 8(4): 1515-1520.

Prasad, Y., Kumar, K. and Mishra, S. B. 2011. Studies on genetic parameters and inter-relationships among yield and yield contributing traits in Pigeonpea [Cajanus cajan (L.) Millsp.]. The Bioscan. 8(1): 207-211.

Hayes, H. K., Immer, F. R. and Smith, D. C. 1955. Methods of Plant Breeding. (2 ed.). Mc Graw Hill Book Co. Inc. New York. p. 551

Al-Jabouri, R. A., Miller, P. A. and Robinson, H. F. 1958. Genotypic and environmental variance in upland cotton cross of interspecific origin. Agron. J. 50: 633-637.

Dewey, D. R. and Lu, K. H. 1959. A correlation and path co-efficient analysis of components of crested wheat grass seed production. Agron. J. 51: 515-518.

Basavaraju, G. H., 2006, Variability studies in dahlia (Dahlia variabilis L.). M. Sc. Thesis, Univ. Agric. Sci., Dharwad, India.

Suvija, N. V., Suresh, J., Subesh, R. K., and Kannan, M., 2016, Evaluation of Chrysanthemum cultivars (Chrysanthemum morifolium Ramat.) Genotypes for loose flower, cut flower and pot mums. Inter. J. Innov. research and advanced studies,3(4): 2394-4404.

Atul, P., Kumar, M., Singh, C., Kumar, A., Badal, D. S. and Singh, S., 2018, Correlation and path analysis studies in chrysanthemum (Dendranthema grandiflora Tzvelev). J. of Pharmacognosy and Phytochemistry . 7(2): 3890-3893.

Singh, D. and Singh, A. K., 2005, Correlation and path coefficient analysis in marigold (Tagetes spp.). Prog. Hort., 37(2): 385-388.

Ravikumar, H. and Patil, V. S., 2003, Genetic variability and character association studies in China aster (Callistephus chinensis) genotype. J. Orna. Hort., 6(3): 222-228.

Naik, B. H., Basavaraj, N. and Patil, V. S., 2004, Correlation studies in China aster (Callisthephus chinensis Ness.) genotypes. J. Orn. Hort., 7(3-4): 8186.

Ranchana, P., Kannan, M. and Jawaharlal, M., 2013, Genetic and correlation studies in Double genotypes of Tuberose (Polianthes tuberosa) for assessing the genetic variability. $A d v$ Crop Sci Tech. 1: 109.

Wright, S., 1921, Correlation and causation. J. Agric. Res., 20: 557-585.

Kameshwari, P. L., Pratap, M., Begum, H. U. and Anuradha, G., 2015, Studies on genetic variability and character 
association for yield and its attributes in chrysanthemum (Dendranthema grandiflora Tzvelev). Agric. Sci. Digest., 35(1): 25-30.

Hebbal, M., Shiragur, M., Naika, M. B. N., Seetharamu, G. K., Nishani, S. and Patil, B. C., 2018, Genotypic and phenotypic path analysis for flower yield inchrysanthemum (Dendranthema grandiflora Tzvelve).
Int.J.Curr.Microbiol.App.Sci. $\quad 7(8)$ : 4515-4521.

Deka, K. K. and Paswan, L., 2002, Correlation and path analysis studies in chrysanthemum. Int. Information System for the Agric. Sci. Technol.4(5): 40-45.

Vishnu Swarup. 1967. Garden Flowers.National book Trust, India.

\section{How to cite this article:}

Bindhushree, M.P., B.C. Patil, Mukund Shiragur, Sateesh R. Patil, Amruta S. Bhat and Dileep Kumar A. Masuthi. 2019. Correlation and Path Analysis in Annual Chrysanthemum [Chrysanthemum coronarium L.]. Int.J.Curr.Microbiol.App.Sci. 8(09): 936-942. doi: https://doi.org/10.20546/ijcmas.2019.809.110 